Henna Pihlajaniemi ${ }^{1}$, Mirja Siuruainen ${ }^{1}$, Kari Laine ${ }^{2}$, Salla Kananen ${ }^{3}$, Sirkka-Liisa Peteri ${ }^{3}$, Aino Hämäläinen ${ }^{1}$ ja Tuomas Kauppila ${ }^{1}$

1) Oulun yliopiston kasvitieteellinen puutarha, PL 3000, 90014 Oulun yliopisto

2) Thule-instituutti, Oulun yliopisto, PL 7300, 90014 Oulun yliopisto

${ }^{3)}$ Lapin ammattiopisto, Luonto- ja ympäristöala, Metsäruusuntie 18, 96400 Rovaniemi

\title{
Kestävää viherrakentamisen ja ennallistamisen kasvimateriaalia pohjoisille matkailualueille
}

\section{Tiivistelmä}

Viherrakentamisen ja ennallistamisen kasvilajien valinta ja saatavuus on pohjoisen vaativissa kasvuolosuhteissa usein ongelma. Syksyllä 2007 päättyi laaja pohjoisille matkailualueille keskittynyt EU LIFE ympäristörahaston hanke Matkailualueet maisemalaboratorioina - Työvälineitä kestävän matkailun edistämiseen (LANDSCAPE LAB). Oulun yliopiston kasvitieteellinen puutarha oli hankkeessa mukana yhtenä kumppanina ja toteutti yhteistyössä Lapin ammattiopiston luonto- ja ympäristöalan toimipisteen kanssa Kestävän viherrakentamisen ja ennallistamisen kasvimateriaali, (LABPLANT) osahankkeen. Osahankkeen tavoitteina oli etsiä ja valita pohjoiseen viherrakentamiseen ja ennallistamiseen sopivaa kasvimateriaalia, kehittää kasvien lisäysmenetelmiä ja tuottaa kestävää kasvimateriaalia, perustaa näytealueita pohjoisiin matkailukeskuksiin ja kirjoittaa opaskirja pohjoisen matkailuympäristön kestävistä kasveista.

Kestävien kasvien valinta perustui oleellisesti jo olemassa olevaan, aiemmista projekteista tulleeseen tietoon sekä Oulun yliopiston kasvitieteellisen puutarhan ja Lapin ammattiopiston Metsäruusun toimipisteen kasvikokoelmiin. Esiteltävän kasvimateriaalin valinnan kriteerit olivat ilmastollinen kestävyys sekä käyttökelpoisuus pohjoisessa ympäristössä. Kasvimateriaali koostuu perinteisistä viherrakentamisen kasveista, luonnonkasveista ja potentiaalisista uusista viherrakentamisen kasveista. Osahankkeen aikana lisättiin yhteensä lähes sata eri lajia tai kantaa monivuotisia ruohokasveja, varpuja, pensaita ja puita.

Osatehtävän aikana perustettiin yhteensä kuusi näyteistutusaluetta, näistä kaksi Leville, kaksi Ylläkselle ja kaksi Pallakselle. Näytealueilla esitellään kasvien käyttöä erilaisissa pohjoisissa matkailuympäristöissä. Valmistunut opaskirja, Pohjoisen matkailuympäristön kestävät kasvit, kertoo pohjoisen ympäristön ja kasvien ominaispiirteistä sekä siitä, miten pohjoisen matkailukeskusten ympäristöistä voidaan kehittää viihtyisämpiä ja ekologisesti kestävämpiä. Opaskirjassa esitellään yli 300 pohjoisilla alueilla käyttökelpoista ja kestävää luonnon- ja viherrakentamisen kasvia lisäys- ja saatavuustietoineen.

Kestävä kasvimateriaali, pohjoinen matkailuympäristö, viherrakentaminen 
Henna Pihlajaniemi ${ }^{1}$, Mirja Siuruainen ${ }^{1}$, Kari Laine $^{2}$, Salla Kananen ${ }^{3}$, Sirkka-Liisa Peteri ${ }^{3}$, Aino Hämäläinen $^{1}$ ja Tuomas Kauppila ${ }^{1}$

1) Oulun yliopiston kasvitieteellinen puutarha, PL 3000, 90014 Oulun yliopisto

2) Thule-instituutti, Oulun yliopisto, PL 7300, 90014 Oulun yliopisto

${ }^{3)}$ Lapin ammattiopisto, Luonto- ja ympäristöala, Metsäruusuntie 18, 96400 Rovaniemi

\section{Kestävää viherrakentamisen ja ennallistamisen kasvimateriaalia pohjoisille matkailualueille}

\section{Johdanto}

Pohjoinen ympäristö on ekologisesti tarkasteltuna karu, herkästi vaurioituva ja hitaasti uusiutuva. Talvi on pitkä ja pimeä, kesä on valoisa mutta lyhyt ja viileä, ja maaperä on karu sekä hapan. Elämän edellytys pohjoisessa on kyky sopeutua paikalliseen ilmastoon ja vuosien välisiin vaihteluihin. Pohjoiset luonnonkasvit ovatkin hyvin sopeutuneet vallitseviin kasvuolosuhteisiin. Luonnonkasveille pohjoinen menestymisraja on usein lisääntymisraja. Vieraalla kasvimateriaalilla raja perustuu talvenkestävyyteen. Istutetun koristekasvin ei välttämättä tarvitse ehtiä kypsyttää siemeniään, kunhan se menestyy muuten kasvupaikallaan.

Pohjoinen matkailuelinkeino panostaa nykyään talvimatkailun lisäksi yhä voimakkaammin myös kesämatkailun kehittämiseen. Talvisesongin jäljiltä matkailukeskusten ympäristöt ovat usein epäsiistejä ja mm. moottorikelkkailun ja rinnekoneiden aiheuttamat vauriot näkyvät maastossa selvästi. Pohjoinen matkailu rakentuu pitkälti luonnon vetovoimaan, jota se kuitenkin toimialaansa kehittäessään kuluttaa. Isot matkailukeskukset muistuttavat jo hyvin kaupunkimaisia ympäristöjä ja niiden viherympäristöjen suunnittelu ja toteutus vaatii kehittämistä, jotta ympäristön vetovoima säilyisi.

Pohjoisessa viherrakentamisessa ja ympäristövaurioiden korjaamisessa on monia ongelmia. Näitä ovat mm. maaperän laadun, rakennetun kasvualustan ja paikalle tuotujen kasvien yhteensopimattomuus, sekä kestävän, paikallisesti tuotetun kasvimateriaalin puute, soveliaan kasvualustan heikko saatavuus ja tiedon puute siitä, mitä kasveja pohjoisilla alueilla voidaan käyttää.

Syksyllä 2007 päättyi laaja pohjoisille matkailualueille keskittynyt EU LIFE ympäristörahaston rahoittama ja Lapin yliopiston arktisen keskuksen koordinoima Matkailualueet maisemalaboratorioina - Työvälineitä kestävän matkailun edistämiseen (LANDSCAPE LAB) -hanke. Hankkeen tavoitteena oli kehittää ja esitellä menetelmiä, joiden avulla arvioidaan ja edistetään matkailun kestävyyttä. Hanke koostui neljästä osahankkeesta, joista Oulun yliopiston kasvitieteellinen puutarha yhdessä Lapin ammattiopiston luonto- ja ympäristöalan toimipisteen kanssa toteutti Kestävän viherrakentamisen ja ennallistamisen kasvimateriaali, (LABPLANT) osahankkeen. LANDSCAPE LAB -hankkeessa oli mukana useita muitakin kumppaneita, kuten MTT, Metla, RKTL, GTK, sekä osarahoittajina Kittilän ja Kolarin kunnat, joiden alueille hankkeen ja sen osahankkeiden toiminta pääosin keskittyi.

\section{Tavoitteet ja tulokset}

LABPLANT -osahankkeen tavoitteina oli 1 . etsiä ja valita pohjoiseen viherrakentamiseen ja ennallistamiseen sopivaa kasvimateriaalia, 2. kehittää kasvien lisäysmenetelmiä, 3. tuottaa kestävää kasvimateriaalia, 4. perustaa pohjoisille matkailualueille näytealueita, joilla esitellään kestäviä kasveja sekä miten viherrakentamista ja ennallistamista voidaan toteuttaa hyvällä ja kestävällä tavalla ja 5 . kirjoittaa opaskirja pohjoisen matkailuympäristön kestävistä kasveista.

\section{Viherrakentamisen ja ennallistamisen kestävä kasvimateriaali}

Kestävien kasvien valinta LABPLANT -osahankkeessa perustui oleellisesti jo olemassa olevaan, aiemmista projekteista tulleeseen tietoon. Pohjoisessa Suomessa on toiminut useita kestävän kasvimateriaalin kartoittamiseen ja taimitarhatuotannon kehittämiseen tähdänneitä hankkeita 1980 luvulta lähtien. Myös Oulun yliopiston kasvitieteellisen puutarhan ja Lapin ammattiopiston Metsäruusun toimipisteen kasvikokoelmista löytyy kasveja pohjoisen viherrakentamisen käyttökasvivalikoiman monipuolistamiseen. Kestävien kasvien käyttökelpoisuuden arvioinnissa hyödynnettiin näiden molempien kumppaneiden kokemuksia sekä asiantuntemusta. 
Kasvivalinnan tuloksena listattiin yli 300 pohjoisessa käyttökelpoista ja ilmastollisesti kestävää kasvilajia/-kantaa, jotka on esitelty osahankkeen julkaisemassa opaskirjassa. Nämä ovat sekä perinteisiä viherrakentamisen kasvilajeja että luonnonkasveja. Aivan kaikkien listattujen kasvilajien menestymisvyöhykkeitä pohjoisessa ei vielä tarkalleen tiedetä. Esittelyssä on myös uusia lajeja, joita ollaan vasta tuomassa taimimarkkinoille.

Havukasveista löytyy pohjoiseen käyttökelpoista materiaalia sekä kotimaisista että ulkolaisista lajeista. Kotimaisista havuista suositaan pohjoisia muotoja kuten siperiankuusta (Picea abies ssp. obovata). Ulkolaisista kestäviä ovat mm. siperianpihta (Abies sibirica), siperiansembra (Pinus cembra ssp. sibirica) ja pensassembra (P. pumila).

Lehtipuista koivut ovat pohjoisen viherrakentamisen ydinpuulajeja. Myös hieskoivun punalehtinen erikoismuoto punakoivu (Betula pubescens f. rubra) on pohjoisessa kestävä. Haapa, lepät ja pihlajat ovat pohjoiseen käyttökelpoisia viherrakentamisen kasveja, jotka sopivat niin rakennettuun kuin luonnontilaiseen ympäristöön. Eteläisessä Lapissa viihtyvät mm. marja (Malus baccata) ja siperianomenapuu ( $M$. prunifolia), tuohituomi (Prunus maackii) sekä pilvikirsikka ( . pensylvanica). Pajujen runsaslajisessa suvussa on monia pohjoisessa käyttökelpoisia puita, pensaita sekä maanmyötäisesti että varpumaisesti kasvavia lajeja. Näistä mainittakoon Kittilästä lisäykseen otettu lettopajun (Salix myrsinites) matalakasvuinen lamoava muoto. Siperianhernepensas (Caragana arborescens), unkarinsyreeni (Syringa josikaea), siperianorapihlaja (Crataegus sanguinea), sipinruusu (Rosa 'Sipi') ja idänvirpiangervo (Spiraea chamaedryfolia) ovat vain muutamia lukuisista pohjoisessa käyttökelpoisista pensaslajeista. Kunhan taimimateriaalia tulee myyntiin, Lapissa kannattaa kokeilla myös Alaskasta peräisin olevaa karpaloheittä (Viburnum edule).

Köynnöksistä kestäviä ovat mm. Lapissa luonnonvaraisena rauhoitettu siperiankärhö (Clematis alpina ssp. sibirica), jonka taimikaupoissa myytävät alkuperät ovat ulkolaisia, humala (Humulus lupulus), jonka emikasvilla on koristeelliset kävyt, ja voimakaskasvuiset puna- ja valkokarhunköynnökset (Calystegia).

Varvut sopivat erityisen hyvin luonnonmukaiseen viherrakentamiseen vaikka ovatkin viljelyssä usein vaikeita lisätä ja hitaita kasvattaa. Osa kotimaisista varvuista on ikivihreitä, ja lajeilla jotka pudottavat lehtensä on yleensä upea ruskaväritys. Varvuista mainittakoon hyvä ruskakasvi juolukka (Vaccinium uliginosum), viljeltynä tuuheaksi kasvava suopursu (Ledum palustre) ja maanpeittokasviksi sopiva lapinvuokko (Dryas octopetala).

Monivuotisten ruohokasvien eli perennojen valikoima on pohjoisessakin suuri. Useista kasvisuvuista löytyy niin perinteisiä koristekasveja, kuin viherrakentamiseen ja ennallistamiseen sopivia luonnonkasveja. Esimerkkinä mainittakoon kurjenpolvet, joista metsäkurjenpolvi (Geranium sylvaticum) sopii hyvin luonnonmukaiseen viherrakentamiseen ja isompikukkainen kyläkurjenpolvi (G. pratense) taas rakennettujen ympäristöjen istutuksiin.

Monivuotisia (koriste)heiniä sekä saniaisia käytetään pohjoisessa vähän ja niitä on myös vähän tarjolla taimistoissa. Kirjavalehtiset heinät sopivat perinteiseen viherrakentamiseen. Monet luonnonheinät, vihvilät, suovillat ja sarat sopivat hyvin luonnonmukaiseen viherrakentamiseen ja ovat käyttökelpoisia ennallistamisen ja ympäristövaurioiden korjaamisen kasveja. Nuokkuhelmikällä (Melica nutans) on kauniit tähkylät, jäkki (Nardus stricta) tekee tiheitä mättäitä, kevätpiipolla (Luzula pilosa) on ainavihannat lehdet ja suokasvi lettonuppisara (Carex capitata) soveltuu kivikkokasviksikin. Saniaisista mainittakoon hiirenportaat (Athyrium) ja alvejuuret (Dryopteris).

Osahankkeen aikana lisättiin yhteensä lähes sata kasvilajia tai -kantaa. Mikrolisäysmenetelmiä kehiteltiin useille lajeille, yhteensä mikrolisättyjä lajeja oli 42 kappaletta. Näistä kasvilajeista esimerkkeinä voidaan mainita seljapihlaja (Sorbus sambucifolia), vaivero (Chamaedaphne calyculata), suokukka (Andromeda polifolia), peuranvirna (Astragalus frigidus), lapinorvokki (Viola biflora) sekä mustasara (Carex atrata). Pistokaslisäyksessä olleet kasvit olivat lähinnä pajuja, kuten tunturipaju (Salix glauca) ja villapaju (Salix lanata). Siemenistä lisättiin ruohovartisia kasveja, luonnonkasveja sekä perennoja kuten väinönputki (Angelica archangelica ssp. archangelica) ja ruusujuuri (Rhodiola rosea). Lisättyä kasvimateriaalia on istutettu näytealueille ja sillä on täydennetty myös kasvitieteellisen puutarhan ja ammattiopiston kasvikokoelmia. 


\section{Näytealueet}

Näytealueet ovat esimerkkejä kasvien käytöstä erilaisissa pohjoisissa matkailuympäristöissä. Osatehtävän aikana perustettiin yhteensä kuusi näyteistutusaluetta, näistä kaksi sijaitsee Levillä, yksi Äkäslompolossa, yksi Ylläsjärvellä sekä kaksi Pallaksella.

Levin isompi näytealue sijaitsee Sirkan keskustassa Hullu Poro Areenan lähellä olevan ulkoilureitin lähtöpisteessä. Alueelle istutettiin pääasiassa luonnonkasveja, kuten pohjanpaju (Salix lapponum), pohjanruttojuuri (Petasites frigidus) sekä kellosinilatva (Polemonium acutiflorum). Toinen Levin näytealueista sijaitsee Levitunturille nousevan tien varrella lähellä puurajaa. Näytealueen ideana oli kasvien käyttö yhdessä tunturikivien kanssa tunturimaisemaa kuvaavassa maataideteoksessa. Siihen istutettiin mm. katajaa (Juniperus communis), kissankäpälää (Antennaria alpina) ja tunturikallioista (Erigeron uniflorus).

Äkäslompolossa näytealueena toimii luontokeskus Kellokkaan sisäpiha. Sinne toteutettiin ns. peräpohjalainen pihapiiri, jossa esitellään sekä perinteisesti pohjoisessa viherrakentamisessa käytettyjä kasveja että pohjoisia luonnonkasveja. Näytealue koostuu yhteensä neljästä erityyppisestä istutusryhmästä, joita ovat kahvilan ovenvierustan perennaistutukset, sisäpihan kerroksellinen kasviistutus, lapinkenttä ja pienoistunturi. Ylläsjärven puolella näytealue sijaitsee laskettelurinteiden alaosassa Bistro Hissi ravintola- ja toimistorakennuksen nurkkauksessa. Luonnonmukaisen viherrakentamisen teemalla kulkevalle näytealueelle istutettiin $\mathrm{mm}$. tornionlaaksonruusua (Rosa majalis 'Tornedal'), kultapiiskua (Solidago virgaurea) ja kertokukkaista puna-ailakkia (Silene dioica fl. pl.).

Pallas-Yllästunturin kansallispuistoon perustettiin kaksi näytealuetta Pallakselle hotellin ja luontokeskuksen läheisyyteen. Molemmilla alueilla pyrittiin korjaamaan pienialaisesti ympäristöä vaurion jäljiltä tukemalla ja nopeuttamalla alueella luontaisesti esiintyvän lajiston palautumista kasviistutusten avulla. Näytealueille istutettiin vain pohjoista alkuperää olevaa ja alueelle luontaisesti kuuluvaa kasvilajistoa kuten esimerkiksi mustikkaa (Vaccinium myrtillus) ja norjanjäkkärää (Gnaphalium norvegicum).

\section{Opaskirja}

Valmistunut opaskirja, Pohjoisen matkailuympäristön kestävät kasvit, kertoo pohjoisen ympäristön ja kasvien ominaispiirteistä sekä siitä, miten pohjoisen matkailukeskusten ympäristöistä voidaan kehittää viihtyisämpiä ja ekologisesti kestävämpiä. Opaskirjassa esitellään yli 300 pohjoisilla alueilla käyttökelpoista ja kestävää luonnon- ja viherrakentamisen kasvia lisäys- ja saatavuustietoineen. Kirja antaa esimerkkejä kasvien käytöstä erilaisilla kasvupaikoilla muiden yhteensopivien kasvilajien kanssa. Myös potentiaalisia uusia viherrakentamisen kasveja, joita ei vielä ole kaupallisesti saatavilla, esitellään. Osahankkeessa valmistuneista näytealueista sekä Olokselle 1990-luvulla perustetusta maataideteoksesta on kuvaukset. Opaskirja on suunnattu ympäristö- ja viherrakentamisalan opetukseen sekä alan suunnittelijoille ja toimijoille, mutta yhtälailla suurelle yleisölle ja puutarhaharrastajille. Opaskirjan sähköinen versio on ladattavissa LANDSCAPE LAB hankkeen www-sivuilta http://www.arcticcentre.org/landscapelab.

\section{Johtopäätökset}

Vaikka pohjoinen ympäristö ja osahankkeen kohdealueena tarkastelema matkailuympäristö asettavat käytettäville kasvilajeille ja viherrakentamisen ja ennallistamisen menetelmille erityisvaatimuksensa, löytyy pohjoisille alueille kestäviä ja toimivia ratkaisuja. Pohjoisessa käytettävän kasvimateriaalin tulee olla ilmastollisesti kestävää ja paikallisiin kasvuolosuhteisiin sopivaa ja mielellään paikallista alkuperää tai lisäyslähdettä. Matkailuympäristössä tulisi pyrkiä korostamaan ja säilyttämään paikallista viherympäristöä ja hyvän suunnittelun avulla sijoittamaan ja toteuttamaan matkailutoiminnot kulutusta kestäville alueille. Suunnittelun lähtökohtana tulisi olla paikalliset luonnonolot ja näitä tulisi myös ympäristövaurioiden korjaamisessa ja viherrakentamisessa kunnioittaa.

Kasvivalinnan pohjana on kasvupaikan luontaisten ominaisuuksien tunteminen. Näitä ovat mm. maaperän ominaisuudet, kosteusolosuhteet sekä talvisen lumipeitteen määrä. Kasvin valintaan vaikuttavat myös kasvilajikohtaiset ominaispiirteet, kuten kasvutapa, juuristotyyppi sekä leviämistapa. Käyttökasveja valittaessa tulisi painottaa paikallisia lajeja ja välttää alueille sopimattomien lajien käyttöä. Aggressiivisesti leviäviä ja luonnonkasvien kanssa risteytyviä lajeja ei pidä käyttää. Kasvien valintaan ja käyttöön erilaisilla alueilla vaikuttavat ko. paikan maan käyttötarkoitus, rakentamisaste 
sekä alueen hoitoluokitus, ja edelleen onko alue rakennettua tai luonnontilaista ympäristöä vaiko näiden välistä vaihettumisaluetta, ns. reunavyöhykettä.

LABPLANT -osahankkeen tulokset on keskeisesti koottu lokakuussa 2007 julkaistuun opaskirjaan. Ne edistävät osaltaan mahdollisuuksia hoitaa ja ylläpitää pohjoisten matkailukeskusten ympäristöjä, korjata niiden jo vaurioituneita ympäristöjä sekä kehittää niistä entistä viihtyisämpiä ja ekologisesti kestävämpiä.

\section{Kirjallisuus}

Jokimäki, J. \& Kaisanlahti-Jokimäki, M.-L. 2005. Kestävän matkailun edistäminen: LANDSCAPE LAB hankkeen sisältö ja tavoitteet. Teoksessa: Tuulentie, S. \& Saarinen, J. (toim.): Kestävät käytännöt matkailun suunnittelussa ja kehittämisessä. Metlan työraportteja/Working Papers of the Finnish Forest Research Institute 20: $114-118$.

Laine, K., Pihlajaniemi, H., Kananen, S., Siuruainen, M., Hämäläinen, A., Kauppila, T. \& Peteri, S.-L. 2007. Pohjoisen matkailuympäristön kestävät kasvit. Kalevaprint Oy, Oulu 2007. 96 s.

http://www.oulu.fi/botgarden

http://www.lao.fi

http://www.arcticcentre.org/landscapelab 